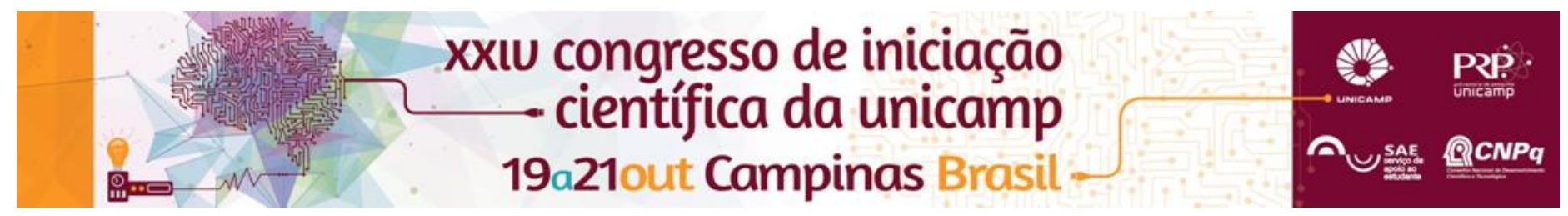

\title{
Desinfecção de efluente secundário por ozonização
}

\section{Ivna M. Seabra Rodrigues*, Josiane A. S. Vendemiatti, Renato Falcão Dantas}

\section{Resumo}

O objetivo do trabalho foi testar o método da ozonização como tratamento terciário para desinfetar um efluente secundário da estação de tratamento da Faculdade de Tecnologia da Unicamp. A concentração de ozônio foi medida ao longo do tempo pelo método colorimétrico de índigo e a desinfecção foi avaliada pela evolução do número mais provável de coliformes totais e fecais (Escherichia Coli) medido pelo método do substrato cromogênico. Posteriormente foi estabelecida uma relação entre concentração de ozônio e a inativação dos microrganismos. O método se mostrou eficaz para a desinfecção, atingindo uma completa inativação em 20 minutos de tratamento, o equivalente a uma concentração de ozônio de $0,4 \mathrm{mg}$ de $\mathrm{O}_{3} / \mathrm{L}$.

\section{Palavras-chave:}

Ozonização, processos oxidativos avançados, coliformes.

\section{Introdução}

Diversas são as doenças causadas pela falta de tratamento eficiente de efluentes. Os microrganismos que causam essas doenças são extremamente variados, mas há um grupo de bactérias cuja presença na água é uma indicação de contaminação fecal, as bactérias do gênero Escherichia. A espécie Escherichia Coli é um dos habitantes mais comuns do trato intestinal humano, e está restrita ao trato intestinal de animais de sangue quente. A determinação da concentração de coliformes totais e fecais nas amostras de água e esgoto é um importante parâmetro indicador da possibilidade de existência de microrganismos patogênicos, transmissores de diversas doenças de veiculação hídrica.

Os processos oxidativos avançados, principalmente o ozônio, têm sido testados no tratamento de esgotos, sendo a maioria dos estudos focados na degradação de contamianntes orgânicos. Esse estudo tem o objetivo de avaliar a capacidade de desinfecção por ozônio de efluente previamente tratado por tratamento biológico convencional.

\section{Resultados e Discussão}

Os experimentos de desinfecção foram realizados em um reator de vidro de $2 \mathrm{~L}$ com um fluxo continuo de ozônio. As amostras foram coletadas em intervalos de tempo de 5 minutos e foi medida tanto a concentração de ozônio aplicado ao sistema quanto de organismos indicadores. O ozônio se mostrou eficaz na inativação dos organismos estudados. Os coliformes totais e as bactérias $E$. Coli mostraram uma resistência semelhante ao ataque pelo ozônio (Figura 1). $\mathrm{O} \mathrm{pH}$ do meio não foi ajustado, sendo assim podemos considerar que a desinfecção foi causada tanto pelo ataque do ozônio molecular quanto pelos radicais hidroxila. A concentração de ozônio necessária para uma completa inativação ficou em torno de $0,4 \mathrm{mg} \mathrm{O}_{3} / \mathrm{L}$, um valor considerado baixo em comparação às doses usadas normalmente no tratamento de efluentes.
Figura 1 - Desinfecção do efluente secundário por ozônio

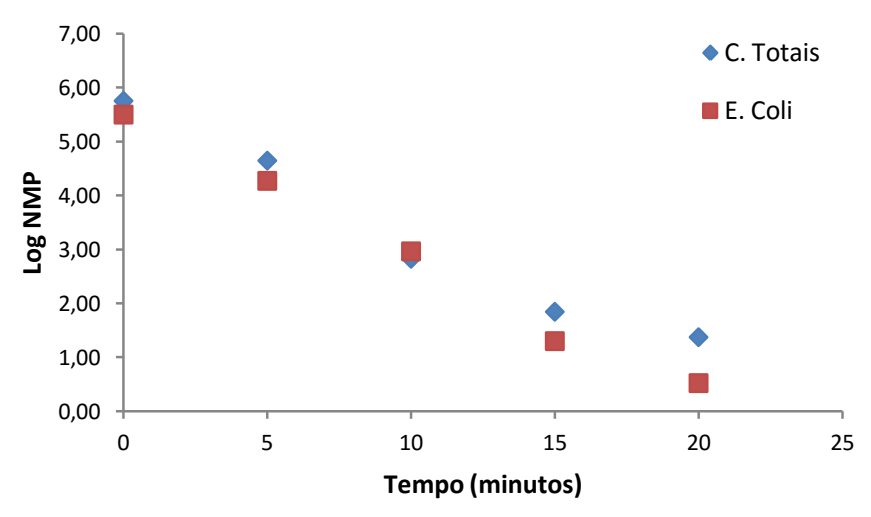

\section{Conclusão}

Ao final dos experimentos foi observada a eficiência do ozônio na inativação de organismos indicadores. Foi constatado que uma etapa de ozonização como tratamento terciário usando uma concentração de menos de $1 \mathrm{~g} / \mathrm{L}$ de $\mathrm{O}_{3}$ seria suficiente para produzir um efluente seguro, com potencial de ser reutilizado.

\section{Agradecimentos}

Os autores agradecem a bolsa PIBIC do CNPq da aluna e à FAPESP pelo financiamento para 0 projeto (JP2014/17774-1)

USEPA. United States Envoronmental Protection Agency. Guidelines for Water Reuse. U.S.EPA., Washington DC, EUA. 2004.

Yuan, X., Lacorte, S., Cristale, J., Dantas, R.F., Sans, C., Esplugas, S., Qiang, Z. Removal of organophosphate esters from municipal secondary effluent by ozone and UV/H ttreatments. Separation and Purification Technology, 2015. 156, pp. 1028-1034. 